\title{
Variability of Soil Properties in Eroded Agricultural Landscape
}

\author{
Agnieszka Wysocka-Czubaszek ${ }^{*}$, Sławomir Roj-Rojewski' \\ 1 Department of Agri-Food Engineering and Environmental Management, Faculty of Civil Engineering and \\ Environmental Sciences, Białystok University of Technology, ul. Wiejska 45A, 15-351 Białystok, Poland \\ * Corresponding author's e-mail: a.wysocka@pb.edu.pl
}

\begin{abstract}
Erosion strongly influences the soil properties and affects the intra-field variation of nutrients not only in steep young morainic landscapes but also on gentle slopes of old-glacial landscapes. The aim of the study was the evaluation of changes in the plant-available nutrient contents in the complex old-glacial eroded landscape of the Bielska Plain in the north-eastern part of Poland. The soil samples were collected from the soil profiles located along the transect beginning on the flat summit of the kame hummock extending through south-facing convex slope, the toeslope and footslope and further through the north-facing uniform slope. The content of plant-available forms of phosphorus $\left(\mathrm{P}_{\mathrm{dl}}\right)$ and potassium $\left(\mathrm{K}_{\mathrm{dl}}\right)$ and mineral forms of nitrogen $\left(\mathrm{NH}_{4}-\mathrm{N}\right.$ and $\left.\mathrm{NO}_{3}-\mathrm{N}\right)$ were determined in every soil profile. The soils located in various landscape positions were characterized with different fertility. In the soil located on the toeslope the content of $\mathrm{NO}_{3}-\mathrm{N}, \mathrm{P}_{\mathrm{dl}}$ and $\mathrm{K}_{\mathrm{dl}}$ was high, while the soil located on the summit was rich in $\mathrm{NH}_{4}-\mathrm{N}$ and poor in the plant-available forms of $\mathrm{K}$ and $\mathrm{P}$. The erosional distribution of plant-available $\mathrm{N}, \mathrm{P}$ and $\mathrm{K}$ enhances the variation of nutrient content within one field and contributes to high variability of crops.
\end{abstract}

Keywords: nitrogen, phosphorus, erosion, old-glacial area

\section{INTRODUCTION}

Erosion is one of the key problems in agriculture causing severe degradation of soil, which is the most important natural resource for food production. In Europe, the water-induced erosion generates the soil loss of $970 \mathrm{Mt}$ per year with mean annual rate of $2.46 \mathrm{t} \cdot \mathrm{ha}^{-1} \cdot \mathrm{yr}^{-1}$ [Panagos et al. 2015] and 115 million hectares (12\%) of Europe's total land area is affected by this process [EC, 2006]. Poland contributes $2.92 \%$ to the total soil loss in European Union (EU) with an average annual rate on arable lands as high as $1.61 \mathrm{t} \cdot \mathrm{ha}^{-1} \cdot \mathrm{yr}^{-1}$ [Panagos et al. 2015]. Globally, on agricultural land, the water erosion rates are equal to $10.6-109.2 \mathrm{t} \cdot \mathrm{ha}^{-1} \cdot \mathrm{yr}^{-1}$ on bare land, 3.9-41.8 $\mathrm{t} \cdot \mathrm{ha}^{-1} \cdot \mathrm{yr}^{-1}$ on cropland, $23.5 \mathrm{t} \cdot \mathrm{ha}^{-1} \cdot \mathrm{yr}^{-1}$ in orchards and 0.3-3.6 th ha ${ }^{-1} \cdot \mathrm{yr}^{-1}$ on grasslands [Xiong et al. 2019]. The water erosion depends on the geomorphological features such as slope steepness, length and shape; soil susceptibility to erosion; climate factors such as precipitation amount, intensity, frequency [Blanco-Canqui, Lal
2008] and the human activities such as land use change, deforestation, overgrazing, agriculture intensification [Panagos et al. 2016].

Another important process of erosional degradation and transformation of soils is tillage erosion with the rate estimated between 3.0 and $9.0 \mathrm{t}^{\mathrm{h}} \mathrm{ha}^{-1} \cdot \mathrm{yr}^{-1}$ [Verheijen et al. 2009]. In the past few decades there has been a shift from the water-dominated to tillage-dominated erosion processes in the agricultural areas, reflecting the increase in mechanized agriculture. The tillage operations generate soil loss of $15-600 \mathrm{t} \cdot \mathrm{ha}^{-1} \cdot \mathrm{yr}^{-1}$ [Blanco-Canqui, Lal 2008] and its rates on undulating areas are similar to those of water erosion [Van Oost et al. 2006], while on hummocky landscapes tillage erosion may be a dominant process of soil translocation [ $\mathrm{Li}$ et al. 2008]. The tillage erosion gradually translocates the soil along the slope during tillage operations and leads to a net downslope displacement of soil, even if upslope and downslope tillage directions are implemented [Govers et al. 1999]. Tillage erosion may cause a serious degradation of soils in sloping cultivated 
landscapes. The tillage erosion rates result from landscape features, soil condition and tillage type, depth, speed and orientation in relation to the slope [Vieira, Dabney 2011]. Tillage and water erosion both contribute to the modification of agricultural landscapes and soils through the removal of topsoil and deposition of eroded material in the depressional sites or its removal to the surface waters as it may happen in the case of water erosion. However, the tillage erosion diminishes the topsoil of hillslopes where water erosion is minimal and deposits material in thalwegs where water erosion is high [Govers et al. 1994].

Erosion strongly influences the soil properties, especially in complex landscapes where surface cation exchange, water-holding capacities and soil organic carbon (SOC), total nitrogen (TN) and total phosphorus (TP) concentrations are higher in depositional areas, comparing to the eroded parts [Wysocka-Czubaszek 2012; Wysocka-Czubaszek et al. 2018]. Soil erosion depletes the SOC stock in arable land and deposits SOC in aquatic ecosystems or in depressional sites where its labile forms may be subjected to decomposition, which leads to the emission of carbon dioxide $\left(\mathrm{CO}_{2}\right)$ under aerobic conditions and methane $\left(\mathrm{CH}_{4}\right)$ under anaerobic conditions. Moreover, the breakdown of aggregates during detachment, splash, transport and redistribution of soil may also expose SOC to microbial processes and release it in gaseous form [Lal 2019]. Soil truncation and nutrient depletion reduce the soil fertility and crop yields. Globally, soil erosion causes a reduction of agri-food production by $33.7 \mathrm{Mt}$ [Sartori et al. 2019]. The nutrient translocation and deposition in low lying areas may also cause non-point pollution [Blanco-Canqui, Lal 2008].

Most studies on water erosion are carried out on susceptible soils [Cheng et al. 2018] or on steep slopes [Xiaojun et al. 2010] while the studies on tillage erosion are primarily conducted on arable fields under conventional tillage [Wang et al. 2019]. The research is mainly focused on SOC, TN and TP redistribution [Xiaojun et al. 2010; Cheng et al. 2018]. Less is known about the erosion effect on plant-available forms of nutrients in the old-glacial landscapes characterized with complex but gentle slopes. The erosional processes are also less often studied in organic farming systems. However, the colluvial deposits observed after rainfalls or spring thawing and the colluvial soils found on the toeslopes [WysockaCzubaszek A. 2012] are the evidence of erosion occurring on the gentle slopes in old-glacial landscapes. The earlier studies of Wysocka-Czubaszek et al. [2018] revealed soil translocation on sloping arable field and changes in some soil chemical properties caused by erosional soil redistribution.

Thus, the objective of this study is the evaluation of changes in the plant-available nutrient contents in the complex old-glacial eroded landscape.

\section{MATERIALS AND METHODS}

\section{Study area}

The study was conducted on the arable field which covered 6.22 ha and was located nearby the Hryniewicze Duże village $\left(52^{\circ} 48^{\prime} 17^{\prime} \mathrm{N}\right.$, $\left.23^{\circ} 12^{\prime} 51^{\prime \prime} \mathrm{E}\right)$ in the Podlaskie Voivodeship, on the Bielsk Plain (Figure 1) in the eastern part of Poland. The study area has undulating topography with small hills associated with the recession of the Wartanian (Saalian) Glaciation [MycielskaDowgiałło et al. 1995] and is characterized by a temperate climate with the continental influences. In the region, the long-term (period of 1961-1995) average annual temperature is $6.8^{\circ} \mathrm{C}$ and long-term (period of 1961-1995) mean annual precipitation is $598 \mathrm{~mm}$, with peaks in June, July and August [Górniak 2000]. The rainfall erosivity index calculated for this part of Poland ranges between 50.6 and $57.9 \mathrm{MJ} \cdot \mathrm{ha}^{-1} \cdot \mathrm{cm}^{-1} \cdot \mathrm{h}^{-1} \cdot \mathrm{yr}^{-1}$ [Banasik, Górski 2000].

The field has been subjected to organic farming practices for the last 15 years. Oat and potatoes with clover as a cover crop have been prevalent crops for last years. The soils are fertilized with horse manure. The tillage operations in the field are performed along the slope gradient, which is a typical tillage direction in this region. The studied transect had a length of $250 \mathrm{~m}$ with elevations of 137.5 to $142.5 \mathrm{~m}$ a.s.l. and extended from the flat summit of the kame hummock through southfacing convex slope with average angle of $7.6 \%$, the toeslope and north-facing uniform slope with average angle of $5.6 \%$ to the summit of next kame hummock (Figure 2).

The morphological features of soils and their main chemical properties vary along the toposequence (Wysocka-Czubaszek et al. 2018), where the soils on slopes are classified according to the Polish Soil Classification (SSSP 2011), as Haplic Luvisols, Haplic Regosols, while those on toeslope and footslope are classified as Haplic 


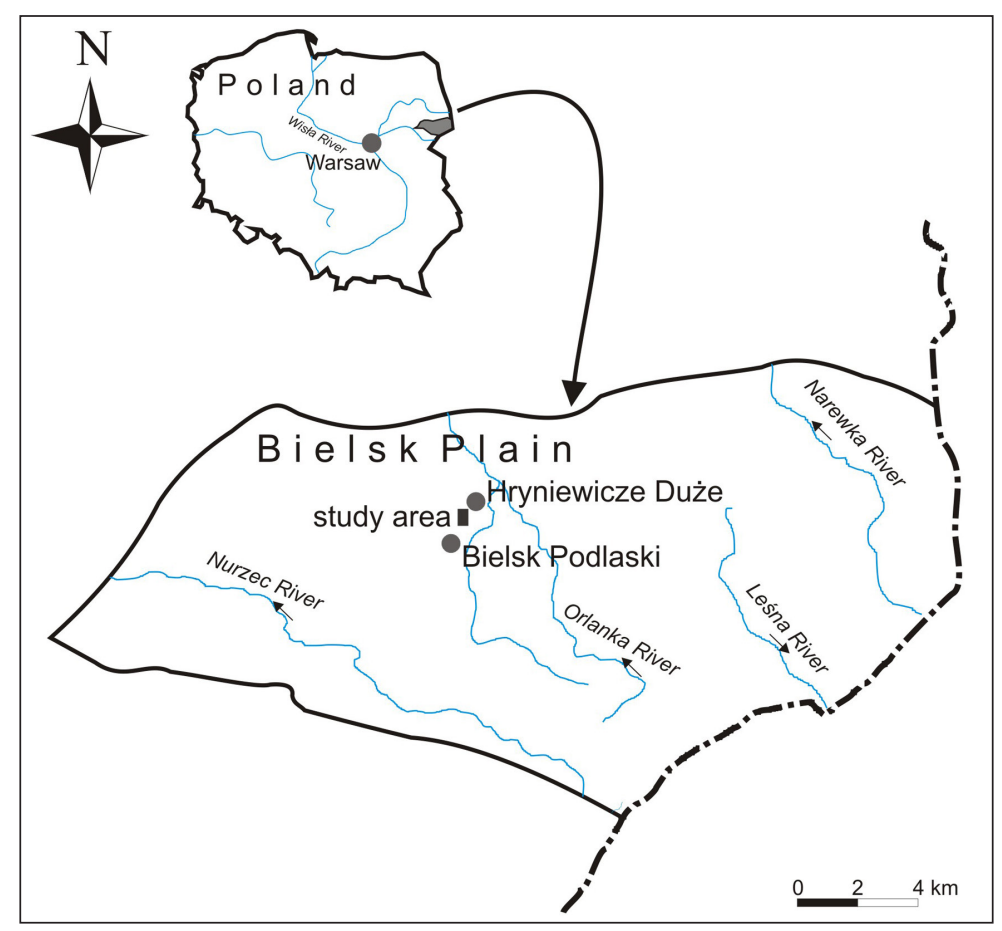

Figure 1. Location of the study site

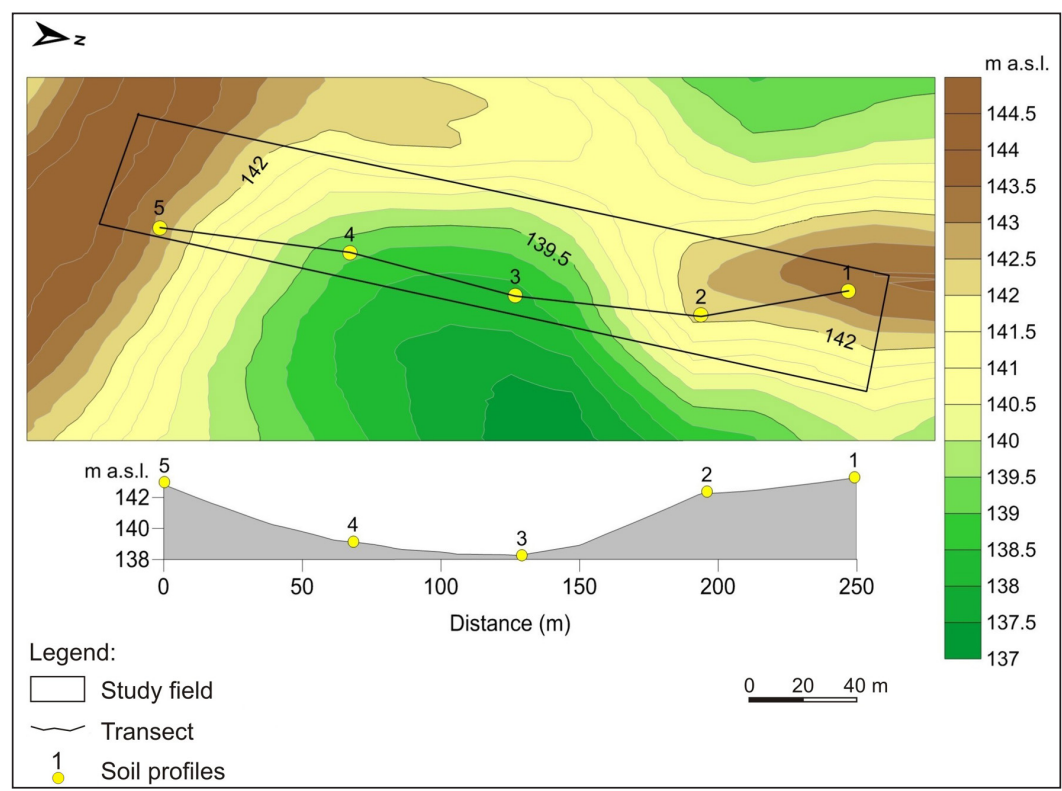

Figure 2. Location of soil profiles at the study site

Cambisols (Eutric) built from the material deposited on the buried soils classified as Cambisol and Luvisol (Figure 3). The main parent materials for these soils are sandy loam and silt loam [Wysocka-Czubaszek et al. 2018].

The region is under the risk of weak erosion according to the Polish method for Actual Water Erosion Risk (AWER) assessment [Wawer et al. 2010] and soil loss calculated according to the Universal Soil Loss Equation ranges from 1 to $5 \mathrm{Mg} \cdot \mathrm{ha}^{-1} \cdot \mathrm{yr}^{-1}$ depending on the slope length and angle and on soil erodibility [WysockaCzubaszek, Czubaszek 2014].

\section{Soil sampling and analysis}

The soil sampling was carried in November 2014. The soil samples were collected from 5 soil profiles located along transect. In each profile, the disturbed soil samples of $1 \mathrm{~kg}$ mass were collected from every morphologic soil horizon. In total, 27 soil samples were taken. 


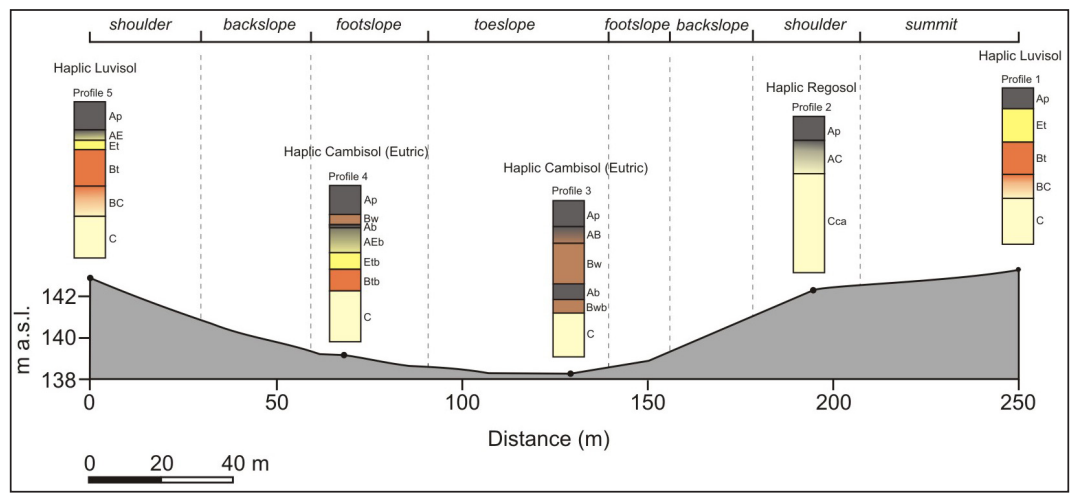

Figure 3. Morphological structure of soils on the toposequence

The analyses of soil chemical properties were performed using the standard procedures. Prior to the analyses, roots and coarse plant debris were removed from the soil samples by hand. The soil moisture of fresh soil samples was determined immediately after collecting and transporting them to the laboratory by oven drying the samples at $105^{\circ} \mathrm{C}$ until they reached a constant mass. The air-dried soil samples were homogenized and sieved through a $2-\mathrm{mm}$ mesh to separate the fine fraction and remove gravel. The inorganic nitrogen $\left(\mathrm{NH}_{4}-\mathrm{N}\right.$ and $\left.\mathrm{NO}_{3}-\mathrm{N}\right)$ was extracted on $10 \mathrm{~g}$ soil sample with $100 \mathrm{~mL}$ of $1 \% \mathrm{~K}_{2} \mathrm{SO}_{4}$ for $24 \mathrm{~h}$ and the concentrations of $\mathrm{NH}_{4}-\mathrm{N}$ and $\mathrm{NO}_{3}-\mathrm{N}$ were measured by UV-1800 spectrophotometer (Shimadzu, Japan) in filtrates. The plant-available phosphorus $\left(\mathrm{P}_{\mathrm{d} l}\right)$, after extraction with calcium lactate solution, was determined with the ammonium metavanadate method using UV-1800 spectrophotometer (Shimadzu, Japan), and the plant-available potassium $\left(\mathrm{K}_{\mathrm{d}}\right)$, after extraction with calcium lactate solution, was analyzed using flame photometry (BWB Technology, USA).

\section{RESULTS}

The soils located in various landscape positions were characterized with different fertility. The $\mathrm{NO}_{3}-\mathrm{N}$ concentration in the profiles ranged from 0.186 to $7.352 \mathrm{mg} \cdot \mathrm{kg}^{-1}$. The highest $\mathrm{NO}_{3}-\mathrm{N}$ content $\left(7.352 \mathrm{mg} \cdot \mathrm{kg}^{-1}\right)$ was found in the Ap horizon of the Haplic Cambisol (Eutric) located on the toeslope (profile 3). The soils located on the south-facing slope were characterized with overall higher amount of $\mathrm{NO}_{3}-\mathrm{N}$ comparing to the soils on the north-facing slope. The $\mathrm{NO}_{3}-\mathrm{N}$ distribution in the soil profiles is shown in Figure 4a. The $\mathrm{N}$ content in the form of ammonium was higher than that in the form of nitrate and ranged in profiles from $3.46 \mathrm{mg} \cdot \mathrm{kg}^{-1}$ to $12.44 \mathrm{mg} \cdot \mathrm{kg}^{-1}$. The content of $\mathrm{NH}_{4}-\mathrm{N}$ in the whole profile was the highest in the Haplic Luvisol located on the flat summit (profile 1) of the kame hummock. The $\mathrm{NH}_{4}-\mathrm{N}$ content of the Ap horizon of this soil was equal to $6.34 \mathrm{mg} \cdot \mathrm{kg}^{-1}$ while in other studied soils, the content of this $\mathrm{N}$ form ranged from $4.11 \mathrm{mg} \mathrm{N}$ $\mathrm{kg}^{-1}$ in the Haplic Luvisol (profile 5) on the shoulder of north-facing slope to $5.60 \mathrm{mg} \mathrm{N} \cdot \mathrm{kg}^{-1}$ in the Haplic Cambisol (Eutric) located on the toeslope (profile 3). The soils located in other positions of the slope were characterized with a similar overall $\mathrm{NH}_{4}-\mathrm{N}$ content (Figure $4 b$ ). In most profiles, the $\mathrm{NH}_{4}-\mathrm{N}$ concentration was uniform along the increasing depth, except the Haplic Luvisol on the summit (profile 1) where the highest $\mathrm{NH}_{4}-\mathrm{N}$ content was observed in the argic (Bt) and underlying transitional (BC) horizons. In the Haplic Cambisol (Eutric) located on the toeslope (profile 3) the $\mathrm{NH}_{4}-\mathrm{N}$ content was the highest in the cambic horizon (Bwb) of the buried Cambisol.

The $\mathrm{P}_{\mathrm{dl}}$ concentration was, according to the Egner-Riehm limit values, low in the Ap horizons of most soils and ranged from $23.35 \mathrm{mg}$ $\mathrm{kg}^{-1}$ in the Haplic Luvisol located on the summit (profile 1) to $40.87 \mathrm{mg} \cdot \mathrm{kg}^{-1}$ in the Haplic Cambisol (Eutric) located on the footslope (profile 4). The concentration of $\mathrm{P}_{\mathrm{dl}}$ in the Ap horizon of the Haplic Cambisol (Eutric) located on the toeslope (profile 3) was the highest $\left(71.21 \mathrm{mg} \cdot \mathrm{kg}^{-1}\right.$ ) and was moderate, according to the Egner-Riehm limit values. The $\mathrm{P}_{\mathrm{dl}}$ content decreased with depth in all profiles; however, in the Haplic Cambisols (Eutric) (profile 4) increased in humic and underlaying horizons of buried soil and then declined in parent material (Figure 5a).

The $\mathrm{K}_{\mathrm{dl}}$ content was, on the other hand, high in most of the Ap horizons and ranged from $144.75 \mathrm{mg} \cdot \mathrm{kg}^{-1}$ in the Haplic Luvisol (profile 5) located on the shoulder of the north-facing slope 

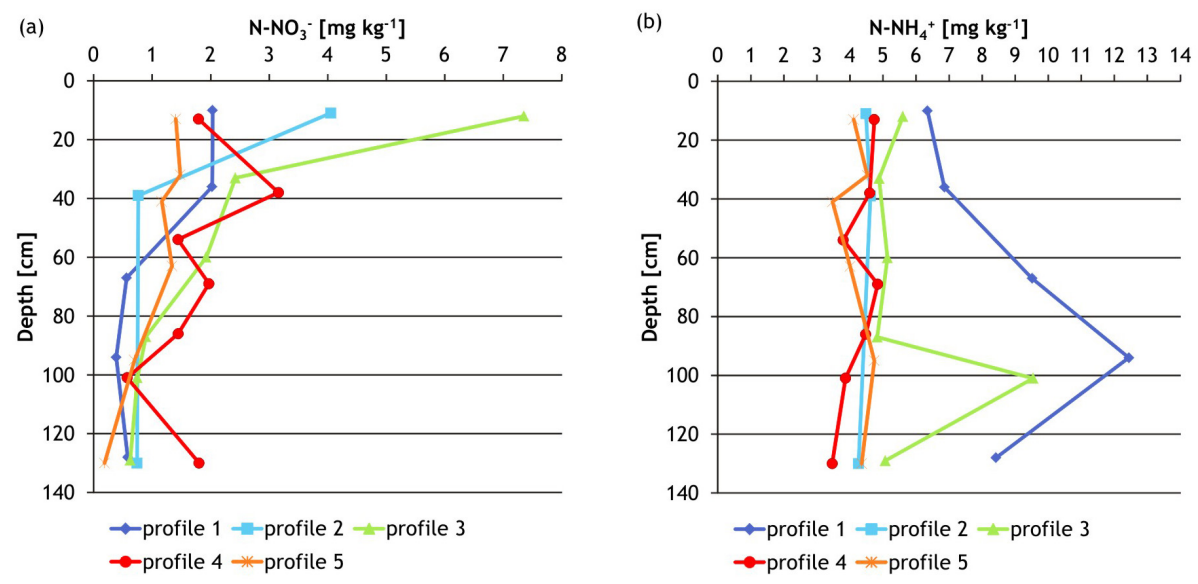

Figure 4. Distribution of $\mathrm{NO}_{3}-\mathrm{N}$ (a) and $\mathrm{NH}_{4}-\mathrm{N}$ (b) in soil profile in various slope positions

to $210.07 \mathrm{mg} \cdot \mathrm{kg}^{-1}$ in the Haplic Cambisols (Eutric) located on the footslope (profile 4). In both lower positions, the $\mathrm{K}_{\mathrm{dl}}$ content in the Ap horizons was very high, according to Egner-Riehm limits. In the soils located on the south-facing slope it was high, while in the soil located on the shoulder of the north-facing slope, it was moderate. The $\mathrm{K}_{\mathrm{dl}}$ distribution along the profile was similar for the soils on the south-facing slope and decreased with the depth from $147.70 \mathrm{mg} \cdot \mathrm{kg}^{-1}$ and $130.81 \mathrm{mg} \cdot \mathrm{kg}^{-1}$ to $18.51 \mathrm{mg} \cdot \mathrm{kg}^{-1}$ and to $2.83 \mathrm{mg} \cdot \mathrm{kg}^{-1}$ for the Haplic Luvisol and the Haplic Regosol, respectively (Figure 5b). In the Haplic Luvisol (profile 5) located on the shoulder of the north-facing slope, the $\mathrm{K}_{\mathrm{dl}}$ content decreased with depth, except for the $\operatorname{argic}(\mathrm{Bt})$ horizon where the increase to $60.22 \mathrm{mg} \cdot \mathrm{kg}^{-1}$ was observed. Even though both Haplic Cambisols (Eutric) were characterized by very high $\mathrm{K}_{\mathrm{dl}}$ in the Ap horizon, the distribution of plant-available $\mathrm{K}$ differed between these two profiles. In the soil located on the toeslope (profile 3), the $\mathrm{K}_{\mathrm{dl}}$ content decreased along the depth from
$182.31 \mathrm{mg} \cdot \mathrm{kg}^{-1}$ in the Ap horizon to $0.83 \mathrm{mg} \cdot \mathrm{kg}^{-1}$ in the cambic horizon of buried Cambisol with small increase in the parent material. In the soil located on the footslope (profile 4) the $\mathrm{K}_{\mathrm{dl}}$ content declined from $210.07 \mathrm{mg} \mathrm{kg}^{-1}$ in the Ap horizon to $2.82 \mathrm{mg} \cdot \mathrm{kg}^{-1}$ in the luvic horizon of buried Luvisol, then increased to $23.74 \mathrm{mg} \cdot \mathrm{kg}^{-1}$ in the argic horizon of this buried soil and again decreased in the parent material to $18.22 \mathrm{mg} \cdot \mathrm{kg}^{-1}$.

\section{DISCUSSION}

The previous studies conducted on the same arable field revealed the truncation of soils located on the south-facing shoulder of the slope and material deposition on the toeslope. Soil redistribution in one arable field with complex topography led to the nutrient and SOC depletion in the soils located in the upper parts of the slope and accumulation of TN, TP and SOC on the toeslope. Differentiation of profile structures together with
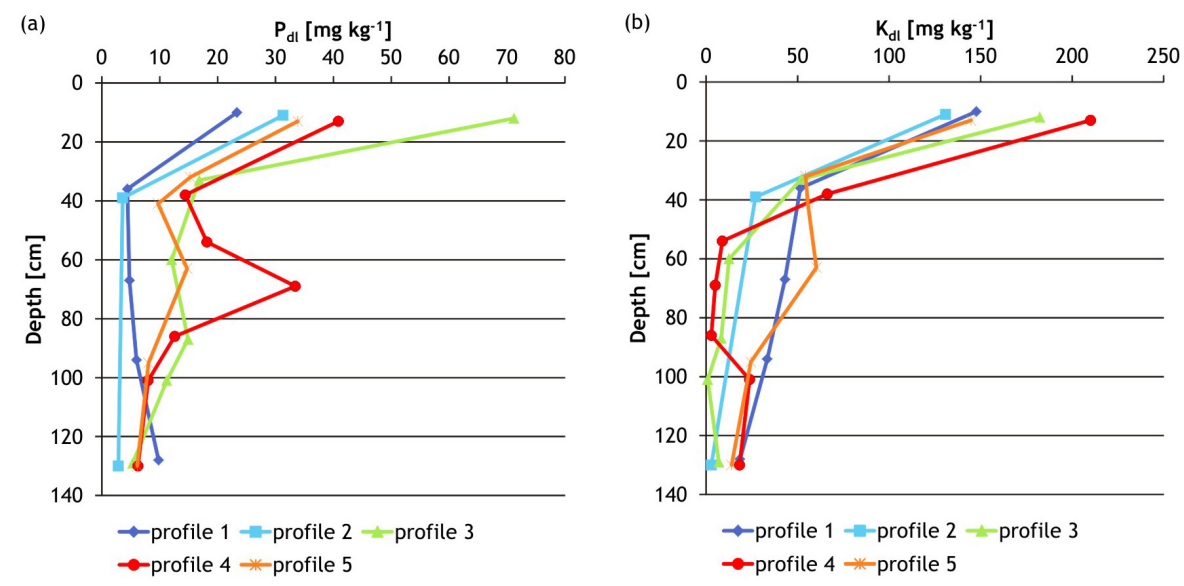

Figure 5. Distribution of $\mathrm{P}_{\mathrm{dl}}(\mathrm{a})$ and $\mathrm{K}_{\mathrm{dl}}$ (b) in soil profile in various slope positions 
SOC, TN and TP redistribution indicates the presence of water and tillage erosion in the studied area [Wysocka-Czubaszek et al. 2018].

The plant-available $\mathrm{N}$ forms in the Ap horizon were very low comparing to other soils under organic farming [Rakotovololona et al. 2019]; however, Lu et al. [2019] reported similar results for soils under wheat monoculture and wheat or maize intercropping. Higher amounts of available $\mathrm{N}$ on the summit and south-facing shoulder than on the north-facing slope are in a good agreement with the results of Zhang et al. [2012] who attributed higher alkali-hydrolyzable $\mathrm{N}$ concentration on summit to lower crops in this position. The increase in available $\mathrm{N}$ in toeslope results from the water and tillage erosion. The higher content of plant available $\mathrm{N}$ in the toeslope position after tillage in the complex slope was reported by $\mathrm{Li}$ et al. [2012]. High $\mathrm{NO}_{3}-\mathrm{N}$ concentration in this part of field may be related to higher moisture. Indeed, the moisture in the Ap horizon in the soil located on the summit was equal to $7.79 \%$, in the soil located on the south-facing slope it was equal to $3.15 \%$ while in the toeslope it was equal to $18.13 \%$. This higher moisture, together with increased SOC might be the reason of faster nitrification rates [Cavalli et al. 2017] which resulted in increased $\mathrm{NO}_{3}-\mathrm{N}$ concentration with rather slight rise of $\mathrm{NH}_{4}-\mathrm{N}$ content in the soil located in the toeslope position.

The vertical distribution pattern of $\mathrm{P}_{\mathrm{dl}}$ in soil profiles is related to the decreasing content of plant and animal debris in soil [Xu et al. 2014]. Application of organic fertilizers only increased $\mathrm{P}_{\mathrm{dl}}$ in the Ap horizons; however, low status of $\mathrm{P}_{\mathrm{dl}}$ is in contradiction with Sharpley et al. [2004] who stated that organic fertilizers were able to increase $\mathrm{P}_{\mathrm{dl}}$ to the greater extent than mineral $\mathrm{P}$ fertilizers due to large amounts of available $\mathrm{P}$. In manure more than $70 \%$ of $\mathrm{P}$ is in inorganic form and therefore it becomes plant-available after application [Eghball et al. 2002]. The increased content of $\mathrm{P}_{\mathrm{dl}}$ in the deeper parts of profiles located in the toe- and footslope indicates the buried soil covered with deposits moved from the upper parts of slopes by water and tillage erosion. The higher $\mathrm{P}_{\mathrm{dl}}$ content in the Ap horizons of the soils located in the lowest positions is also the evidence of erosional processes in the area. Topography has a major influence on the $\mathrm{P}_{\mathrm{dl}}$ spatial distribution by affecting the runoff and erosion, which are the dominant processes, leading to $\mathrm{P}$ redistribution in the landscape [Xu et al. 2014].
Similar findings for TP in the studied area were reported by Wysocka-Czubaszek et al. [2018] who observed TP enrichment of soils on the toeand footslope. The results of this study are also in a good agreement with Zhang et al. [2008] who reported erosional spatial distribution of $\mathrm{P}$ in the hilly landscape.

The plant-available K content in the Ap horizons of all soils was very high due to fertilization with horse manure which was characterized by much higher $\mathrm{K}$ content $\left(9.0 \mathrm{~kg} \mathrm{~K}_{2} \mathrm{O} \mathrm{t}^{-1}\right)$ comparing to the cattle manure $\left(6.5 \mathrm{~kg} \mathrm{~K}_{2} \mathrm{O} \mathrm{t}^{-1}\right)$ [Maćkowiak, Żebrowski 2000] and was available for plants nearly in $100 \%$ [Eghball et al. 2002]. The increase of $\mathrm{K}_{\mathrm{dl}}$ in the soils located in the toe- and footslope positions is in a good agreement with Li et al. [2012]. Nevertheless, the results of this study are contrary with Zhang et al. [2012] who observed the highest $\mathrm{K}_{\mathrm{dl}}$ value at the backslope position; however, the differences in $\mathrm{K}_{\mathrm{dl}}$ along the slope were insignificant.

Organic farming is perceived as an alternative to the conventional farming system because it has better influence on the environment [Cisilino et al. 2019] through improvement of soil quality [Seidel et al. 2017], enlargement of both plant and animal biodiversity [Nascimbene et al. 2012; Tuck et al. 2014], especially in complex landscapes [Feber et al. 2015], and reduction of nitrate in ground and surface water [Tuomisto et al. 2012]. However, the overall environmental impact of organic farming is far more positive than conventional farming, in the case of energy efficiency, the emission of greenhouse gases and erosion the results of organic farming performance are inconsistent [Lee, Choe 2019]. According to Arnhold et al. [2014] organic farming alone cannot effectively control erosion on row crop fields; however, recent conversion to organic farming on silty soils improved the aggregate stability and consequently reduced soil erosion [Morvan et al. 2018]. Therefore, other erosion controls should be implemented in addition to typical for organic farming agricultural practices which are also perceived as erosion prevention such as organic fertilizers applications, catch crops and intercropping.

One of the most common and cheapest soil erosion controls is tillage perpendicular to the slope; however, in a very complex landscape, very often it is difficult or even impossible to operate the tools and keep this direction constantly. Even contour farming characterized with tillage operation performed along lines of consistent elevation may 
be difficult to perform due to the technical reasons. Short slopes, small hummocks and depressional sites in between create the landscape in which such agricultural techniques may not be possible. Therefore, other erosion controls may be more effective. Cover crops combined with reduced tillage may be a good option for organic farming to reduce erosion in complex landscape. Cover crops are established with conventional tillage and then terminated with a roller-crimper and follow by cash crop no-till seeding into the cover crop mulch which provides weed control without herbicides or tillage [Halde et al. 2015]. Micro-basin tillage is one of soil conservation practices which involve preparing individual block of earth along the furrows to retain the surface runoff by increasing the infiltration, rainfall use efficiency and soil water content. Therefore, the soil loss can be effectively controlled by micro-basin tillage and thus may enhance the crop yield [Sui et al. 2016].

The differences in the plant-available nutrients in complex landscape like the study area may be compensated through precision agriculture (PA) which is based on observation, measurement and response to inter and intra-field variability of soil quality or crops yield. PA is mostly advanced in the farms with large field size and is an expensive system introducing global position system (GPS), geographical information system (GIS) and other technologies to agricultural management. The high prices of PA, complexity of eroded landscape and small fields may create some difficulties. Precision fertilization with organic fertilizers is also difficult because organic fertilizers are not as well defined and predictable as the mineral ones [Rütting et al. 2018] and create technical problems with precise application on various parts of the field.

New organic fertilizers, such as digestate which is a by-product of biogas production, can be considered more useful in precision fertilization because digestate can be spread or injected with trailing hose like slurry to the soil. In mixed organic farming, the biogas production and digestate utilization as fertilizer fits in the idea of eco-friendly food production through reduction of greenhouse gases (GHG) emissions. The application of digestate on the field also promotes low GHG emissions [Czubaszek 2019]; however, intensive mineralization of digestate after its application may not give the expected effects in terms of soil protection and its enrichment in organic matter [Czubaszek, Wysocka-Czubaszek 2018].

\section{CONCLUSIONS}

The plant-available forms of $\mathrm{N}, \mathrm{P}$ and $\mathrm{K}$ are unevenly distributed in complex landscape within one arable field as an effect of soil translocation through water and tillage erosion. The soil location in various slope positions also affects the nutrient distribution along the profiles. The soils on toe- and footslope are rich in $\mathrm{P}_{\mathrm{dl}}$ and $\mathrm{K}_{\mathrm{dl}}$, while higher $\mathrm{NO}_{3}-\mathrm{N}$ content results from higher moisture which is beneficial for nitrification processes. The increased content of available N, P and K in deeper horizons of soils located in the depressional site results from buring the original soil with the material dragged and washed from the upper parts of the slope. Tillage and water erosion contribute to the higher variability of nutrients within one field in the complex landscape, which may result in inefficiently used nutrient-rich soils occuring in the mosaic of poorer soils.

\section{Acknowledgements}

This work was financially supported by Ministry of Science and Higher Education as a part of the project $\mathrm{S} / \mathrm{WBiIS} / 01 / 17$.

\section{REFERENCES}

1. Arnhold S., Lindner S., Lee B., Martin E., Kettering J., Nguyen T.T., Koellner T., Ok Y.S., Huwe B. 2014. Conventional and organic farming: Soil erosion and conservation potential for row crop cultivation. Geoderma, 219-220, 89-105.

2. Banasik K., Górski D. 2000. Estimating the rainfall erosivity for East and Central Poland. Proc. I CD Hydroscience and Engineering, Seul, Korea, Sept. 26-29.2000.

3. Blanco-Canqui H., Lal R. 2008. Principles of soil conservation and management. Springer, Dordrecht Heidelberg London NewYork.

4. Cavalli D., Corti M., Baronchelli D., Bechini L., Marino Gallina P. 2017. CO2 emissions and mineral nitrogen dynamics following application to soil of undigested liquid cattle manure and digestates. Geoderma, 308, 26-35.

5. Cheng Y., Li P., Xu G., Li Z., Gao H., Zhao B., Wang T., Wang F., Cheng S. 2018. Effects of soil erosion and land use on spatial distribution of soil total phosphorus in a small watershed on the Loess Plateau, China. Soil \& Tillage Research, 184, 142-152.

6. Cisilino F., Bodini A., Zanoli A. 2019. Rural development programs' impact on environment: An 
ex-post evaluation of organic farming. Land Use Policy, 85, 454-462.

7. Czubaszek R. 2019. Exchange of carbon dioxide between the atmosphere and the maize field fertilized with digestate from agricultural biogas plant. Journal of Ecological Engineering, 20(1), 145-151.

8. Czubaszek R., Wysocka-Czubaszek A. 2018. Emissions of carnon dioxide and methane from fields fertilized with digestate from an agricultural biogas plant. International Agrophysics, 32, 29-37.

9. EC, European Commission 2006. Thematic strategy for soil protection. Impact assessment of the thematic strategy on soil protection. Document accompanying the communication from the Commission to the Council, the European Parliament, the European Economic and Social Committee and the Committee of the Regions. Commission staff working document. COM(2006)231 final, SEC(2006)1165.

10. Eghball B., Wienhold B.J., Gilley J.E., Eigenberg R.A. 2002. Mineralization of manure nutrients. Journal of Soil and Water Conservation, 57(6), $470-473$.

11. Feber R.E., Johnson P.J., Bell J.R., Chamberlain D.E., Firbank L.G., Fuller R.J., Manley W., Mathews F., Norton L.R., Townsend M., Macdonald D.W. 2015. Organic Farming: Biodiversity Impacts Can Depend on Dispersal Characteristics and Landscape Context, PLoS One 10(8) doi: 10.1371/ journal.pone.0135921; https://journals.plos.org/ plosone/

12. article?id=10.1371/journal.pone.0135921.

13. Górniak A. 2000. The climate of the Podlaskie Voivodeship [In Polish]. IMGW, Białystok.

14. Govers G., Lobb D.A., Quine T.A. 1999. Preface - tillage erosion and translocation: emergence of a new paradigm in soil erosion research. Soil \& Tillage Research, 51(3-4), 167-174.

15. Govers G., Vandaele K., Desmet P., Poesen J., Bunte K. 1994. The role of tillage in soil redistribution on hillslopes. European Journal of Soil Science, 45, 469-478.

16. Halde C., Bamford K.C., Entz M.H. 2015. Crop agronomic performance under a six-year continuous organic no-till system and other tilled and conventionally-managed systems in the northern Great Plains of Canada. Agriculture, Ecosystems and Environment, 213, 121-130.

17. Lal R. 2019. Accelerated soil erosion as a source of atmospheric CO2. Soil \& Tillage Research, 188, $35-40$.

18. Lee K.S., Choe Y.C. 2019. Environmental performance of organic farming: Evidence from Korean small-holder soybean production. Journal of Cleaner Production, 211, 742-748.

19. Li F., Zhang J., Su Z. 2012. Changes in SOC and
Nutrients under Intensive Tillage in Two Types of Slope Landscapes. Journal of Mountain Science, 9, 67-76.

20. Li S., Lobb D.A., Lindstrom M.J., Farenhorst A. 2008. Patterns of water and tillage erosion on topographically complex landscapes in the North American Great Plains. Journal of Soil and Water Conservation, 63(1), 37-46.

21. Lu J., Bai Z., Velthof G.L., Wu Z., Chadwick D., Ma L. 2019. Accumulation and leaching of nitrate in soils in wheat-maize production in China. Agricultural Water Management, 212, 407-415.

22. Maćkowiak C., Żebrowski J. 2000. Chemical composition of farmyard manure in Poland [In Polish]. Nawozy i Nawożenie 4(5), 119-130.

23. Morvan X., Verbeke L., Laratte S., Schneider A.R. 2018. Impact of recent conversion to organic farming on physical properties and their consequences on runoff, erosion and crusting in a silty soil. Catena, $165,398-407$.

24. Mycielska-Dowgiałło E., Pękalska A., Woronko B. 1995. The evolution of a marginal forms and kames in the region of Bielsk Podlaski. Quaestionare Geographica, 4, 215-222.

25. Nascimbene J., Marini L., Paoletti M.G. 2012. Organic Farming Benefits Local Plant Diversity in Vineyard Farms Located in Intensive Agricultural Landscapes. Environmental Management, 49, 1054-1060.

26. Panagos P., Borrelli P., Poesen J., Ballabio C., Lugato E., Meusburger K., Montanarella L., Alewell C. 2015. The new assessment of soil loss by water erosion in Europe. Environmental Science \& Policy, 54, 438-447.

27. Panagos P., Imeson A., Meusburger K., Borrelli P., Poesen J., Alewell C. 2016. Soil conservation in Europe: wish or reality? Land Degradation \& Development, 27(6), 1547-1551.

28. Rakotovololona L., Beaudoin N., Ronceux A., Venet E., Mary B. 2019. Driving factors of nitrate leaching in arable organic cropping systems in Northern France. Agriculture, Ecosystems and Environment, 272, 38-51.

29. Rütting T., Aronsson H., Delin S. 2018. Efficient use of nitrogen in agriculture. Nutrient Cycling in Agroecosystems, 110, 1-5.

30. Sartori M., Philippidis G., Ferrari E., Borrelli P., Lugato E., Montanarella L., Panagos P. 2019. A linkage between the biophysical and the economic: Assessing the global market impacts of soil erosion. Land Use Policy, 86, 299-312.

31. Seidel R., Moyer J., Nichols K., Bhosekar V. 2017. Studies on long-term performance of organic and conventional cropping systems in Pennsylvania. Organic Agriculture, 7, 53-61. 
32. Sharpley A.N., McDowell R.W., Kleinman P.J.A. 2004. Amount, forms and solubility of phosphorus in soils receiving manure. Soil Science Society of America Journal, 68, 2048-2057.

33. SSSP 2011. Soil Science Society of Poland, Polish soil classification [In Polish]. Roczniki Gleboznawcze, 62(3).

34. Sui Y., Ou Y., Yan B., Xu X., Rousseau A. N., Zhang Y. 2016. Assessment of micro-basin tillage as a soil and water conservation practice in the Black Soil Region of Northeast China. PLoS ONE 11(3), e0152313. doi:10.1371/journal. pone.0152313, https://journals.plos.org/plosone/ article?id=10.1371/journal.pone.0152313

35. Tuck S.L., Winqvist C., Mota F., Anström J., Turnbull L.A., Bengtsson J. 2014. Land-use intensity and the effects of organic farming on biodiversity: a hierarchical meta-analysis. Journal of Applied Ecology, 51, 746-755.

36. Tuomisto H.L., Hodge I.D., Riordan P., Macdonald D.W. 2012. Does organic farming reduce environmental impacts? - A meta-analysis of European research. Journal of Environmental Management, $112,309-320$.

37. Van Oost K., Govers G., De Alba S., Quine T.A. 2006. Tillage erosion: a review of controlling factors and implications for soil quality. Progress in Physical Geography, 30, 443-466.

38. Verheijen F.G.A., Jones R.J.A., Rickson R.J., Smith C.J. 2009. Tolerable versus actual soil erosion rates in Europe. Earth-Science Reviews, 94, 23-38.

39. Vieira D.A.N., Dabney S.M. 2011. Modeling edge effects of tillage erosion. Soil \& Tillage Research, 111, 197-207.

40. Wang X., Jelinski N.A., Toner B., Yoo K. 2019. Long-term agricultural management and erosion change soil organic matter chemistry and association with minerals. Science of the Total Environment, 648, 1500-1510.

41. Wawer R., Nowocień E., Podolski B. 2010. Actual water erosion risk in Poland based upon Corine
Land Cover 2006. Electronic Journal of Polish Agricultural Universities, 13(2), http://www.ejpau. media.pl/volume13/issue2/art-13.html.

42. Wysocka-Czubaszek A. 2012. Morphology and chemical properties of plough horizons of soils in various slope positions. Polish Journal of Soil Science, 45 (1), 69-82.

43. Wysocka-Czubaszek A., Czubaszek R. 2014. Quantification of water erosion rates on the Narew river valley-sides using Universal Soil Loss Equation. Polish Journal of Soil Science, 47(1), 1-16.

44. Wysocka-Czubaszek A., Czubaszek R., Roj-Rojewski S. 2018. Variability of soil properties of eroded hillslopes in rolling old glacial landscape. Electronic Journal of Polish Agricultural Universities, 21(3), http:/www.ejpau.media.pl/volume21/issue3/ art02.html

45. Xiaojun N., Xiaodan W., Suzhen L., Shixian G., Haijun L. 2010. 137Cs tracing dynamics of soil erosion, organic carbon and nitrogen in sloping farmland converted from original grassland in Tibetan plateau. Applied Radiation and Isotopes, 68, 1650-1655.

46. Xiong M., Sun R., Chen L. 2019. A global comparison of soil erosion associated with land use and climate type. Geoderma, 343, 31-39.

47. Xu G., Li Z., Li P., Zhang T., Cheng S. 2014. Spatial variability of soil available phosphorus in a typical watershed in the source area of the middle Dan River, China. Environmental Earth Sciences, 71, 3953-3962.

48. Zhang J.H., Nie X.J., Su Z.A. 2008. Soil profile properties in relation to soil redistribution by intense tillage on a steep hillslope. Soil Science Society of America Journal, 72(6), 1767-1773.

49. Zhang X., Li Z., Zeng G., Xia X., Yang L., Wu J. 2012. Erosion effects on soil properties of the unique red soil hilly region of the economic development zone in southern China. Environmental Earth Sciences, 67, 1725-1734. 